\title{
Meningkatkan Kemampuan Guru dalam Proses Pembelajaran Melalui Supervisi Kelas
}

\section{Wagiyem $^{*}$}

\section{A R T I C L E I N F O}

Article history:

Received 19 August 2020

Received in revised form

30 September 2020

Accepted 10 October 2020

Available online 29

November 2020

\section{Kata Kunci:}

Kemampuan, supervisi

kelas.

Keywords:

Ability, supervision, class.
A B S T R A K

Tujuan penulisan penelitian tindakan sekolah ini adalah untuk menganliasis efektifitas supervisi kelas untuk meningkatkan kemapuan guru dalam prose pembelajaran. Jenis penelitian yang dilakukan adalah PTK. Subjek penelitia ini sebanyak 27 orang guru. Metode pengumpulan datanya adalah studi dokumen, dan observasi. Metode analisis datanya adalah deskriptif dan untuk data kuantitatif dengan menggunakan intrumen supervisi. Hasil yang diperoleh dari penelitian ini adalah bahwa supervisi kelas dapat meningkatkan kemampuan atau kompetensi profesional guru dalam pembelajaran bagi guru-guru di SMP Negeri 6 Batam. Ini terbukti dari proses dan hasil yang diperoleh pada Siklus I meningkat rata-ratanya menjadi lebih baik yaitu 81,48 \% Demikian juga pada Siklus II naik rata-ratanya menjadi lebih tinggi lagi yaitu 85,19\%. Simpulan yang diperoleh dari penelitian ini adalah gabungan supervisi kelas dan Penyusunan Penelitian Tindakan Sekolah dapat meningkatkan kemampuan atau kompetensi profesional guru dalam pembelajaran.

\section{A B S T R A C T}

This research was conducted at SMP Negeri 6 Batam, Riau Islands Province. The purpose of this School Action Research was to see whether the ability of teachers could be improved through Class Supervision and School Action Research Compilation at SMP Negeri 6 Batam. The data method is document study and observation. The data analysis method is descriptive and for quantitative data, supervision instruments are used (attached). The results obtained from this study are that classroom supervision can improve the ability or professional competence of teachers in learning for teachers at SMP Negeri 6 Batam. This is evident from the process and the results obtained in Cycle I increased on average to be better, namely $81.48 \%$ Likewise in Cycle II, the average increase returned to be even higher, namely $85.19 \%$. The conclusion obtained from this research is that the combination of classroom supervision and the preparation of school action research can improve the ability or professional competence of teachers in learning.

\section{Pendahuluan}

Di era milenial seperti saat ini pendidikan menempati posisi yang sangat penting dalam perkembangan manusia (Sarica \& Cavus, 2009). Tuntutan pekerjaan, hobi, bahkan gaya hidup mendorong sebagian besar orang untuk selalu belajar dalam setiap kondisi kehidupannya. Negara Republik Indonesia memiliki sebuah sistem pendidikan yang telah dikembangkan sejak tahun 1947 melalui kurikulum yang pertama kali diterapkan yaitu rencana pelajaran 1947. Perkembangan zaman memberikan peluang bagi para pakar pendikan untuk menyusun sebuah sistem pendidikan yang sesuai dan dapat menjiwai semangat Pancasila sebagai dasar negara Indonesia. Membangun sebuah sistem pendidikan tentunya membutuhkan banyak pertimbangan dari berbagai aspek dan komponen yang terkandung dalam masyarakat. Hubungan yang terjalin dalam setiap komponen tersebut didasarkan pada sebuah tujuan

Copyright (C) Universitas Pendidikan Ganesha. All rights reserved 
yang telah direncanakan (Adha, 2019). Tujuan Pendidikan adalah untuk menghasilkan manusia yang lebih baik dan bermutu.

Manusia membutuhkan pendidikan dalam kehidupannya. (Pradja, 2008) menyatakan bahwa pendidikan merupakan usaha agar manusia dapat mengembangkan potensi dirinya melalui proses pembelajaran. Kegiatan pendidikan pada umumnya dilaksanakan disetiap jenjang pendidikan melalui kegiatan belajar mengajar. Pendidikan bermutu adalah pendidikan yang mampu mengembangkan potensi-potensi positif yang terpendam dalam diri siswa didik. Dengan pendidikan bermutu, pendidikan menghasilkan tenaga-tenaga muda potensial yang tangguh dan siap bersaing dalam masyarakat dunia. Oleh karena itu, upaya peningkatan mutu pendidikan merupakan hal yang tidak dapat ditawar lagi dalam rangka meningkatkan mutu sumber daya bangsa Indonesia (Widodo, 2015). Sumber daya manusia yang bermutu hanya dapat diwujudkan dengan pendidikan yang bermutu. Untuk menghasilkan Pendidikan yang bermutu tidak terlepas dari peranan guru sebai teman belajar siswa. Peserta didik dan guru memiliki peranan penting dalam kegiatan belajar mengajar (Suryana, 2018).

Guru memberikan peranan penting didalam pendidikan terutama didalam kegiatan belajar mengajar, agar kegiatan belajar mengajar berhasil maka guru dituntut untuk menguasai dan memahami berbagai keterampilan yang dapat mendukung efektivitas dan efesiensi kegiatan belajar mengajar. Guru adalah salah satu komponen pendidikan yang sangat berperan dalam usaha pembentukan sumber daya manusia yang potensial di bidang pembangunan. Oleh karena itu, guru merupakan salah satu unsur kependidikan harus berperan serta secara aktif dalam menempatkan kedudukannya sebagai tenaga profesional. Pada diri guru terletak tanggung jawab untuk membawa siswa pada suatu kedewasaan atau taraf kematangan tertentu. (Sardiman, 2012) mengatakan bahwa guru tidak sematamata sebagai "pengajar" yang melakukan transfer of knowledge, tetapi juga sebagai "pendidik" yang melakukan transfer of values dan "pembimbing" yang memberikan pengarahan dan menuntun siswa dalam belajar" (Firmansyah, 2015).

Rendahnya mutu pendidikan di Indonesia bukan hanya pada level perguruan tinggi, melainkan pada level yang ada di bawahnya sampai pada level yang paling rendah. Tuntutan terhadap lulusan dan layanan lembaga pendidikan yang bermutu semakin mendesak karena semakin ketatnya persaingan dalam lapangan kerja. Hal ini menjadikan persaingan antar lembaga penyelenggara pendidikan dan pasar kerja semakin berat. Peningkatan mutu pendidikan menjadi hal yang perlu ditingkatkan untuk mengantisipasi perubahan-perubahan yang begitu cepat serta tantangan yang semakin besar dan kompleks (Miftachurrahman \& Atika, 2018). Pemerintah telah melaksanakan berbagai proyek pendidikan, di antaranya pengembangan kurikulum, Manajemen Peningkatan Mutu Berbasis Sekolah (MPMBS), peningkatan layanan dan koleksi perpustakaan, Bantuan Meningkatkan Manajemen Mutu (BOMM), Bantuan Imbal Swadaya (BIS), Pengadaan Buku Paket, Peningkatan Mutu Guru, Dana Bantuan Langsung (DBL), Bantuan Operasional Sekolah (BOS), dan Bantuan Khusus Murid (BKM). Selain itu, pemerintah juga terus berusaha menanamkan kesadaran pendidikan terhadap masyarakat, sehingga masyarakat berpartisipasi dalam meningkatkan mutu pendidikan (Djihadah, 2020).

Selain itu kemajuan teknologi disegala bidang dan munculnya pembaharuan-pembaharuan dari masyarakat intelektual berimbas langsung dengan sendirinya ke dunia pendidikan. Proses pembelajaran secara cepat berubah sesuai dengan munculnya paradigma-paradigma baru. Guru harus terus menerus melakukan adaptasi terhadap perubahan tersebut, demi terpuaskannya tuntutan masyarakat. Kondisi ini harus dipertahankan dalam keadaan stabil sampai siswa berhasil lulus dari suatu institusi pendidikan. Berkait dengan masalah pembelajaran maka kondisi proses pembelajaran yang dilakukan oleh guru di SMP Negeri 6 Batam setelah dilakukan pemantauan masih tergolong rendah dengan sampel 27 guru yang dipantau maka 19 berkategori cukup dan 8 orang guru yang berkategori baik. Hal ini harus diupayakan untuk peningkatan kemampuan guru dalam proses pembelajaran. Maka alternatif yang dilakukan oleh kepala sekolah adalah melalu supervisi kelas secara berkesinambungan. Stabilitas suatu kegiatan akan terjadi apabila dilakukan pemantauan atau controlling dengan baik, benar, dan berkelanjutan.

Salah satu controlling untuk pelaksanaan pembelajaran di antaranya yaitu supervisi kelas. Supervisi kelas merupakan upaya dan cara untuk melakukan pemantauan mutu pendidikan secara mikro dan bersifat internal (Hadi, 2019; Muspawi, 2017). Kegiatannya dilaksanakan secara koordinatif antar tenaga edukatif dalam hal ini guru dengan kepala sekolah, guru dengan guru senior, dan guru dengan guru satu rumpun mata pelajaran atas bimbingan dan pemantauan oleh pengawas sekolah. Seluruh pelaku supervisi harus menyadari tujuan hakiki supervisi. Bukan untuk mencari kesalahan, tetapi memperbaiki kekurangan, dan mencari solusi dari kesulitan yang timbul dalam proses pemelajaran. Setelah supervisi selesai, diadakan dialog sebagai evaluasi, mencari solusi atau mendiskusikan hal-hal yang perlu direvisi. Hal penting dicatat untuk ditindaklanjuti secara pribadi oleh guru yang bersangkutan, dan oleh kepala sekolah sebagai bahan pembinaan. Diharapkan ada komitmen baru untuk supervisi berikutnya pasca revisi. 
Hasil penelitian yang dilakukan oleh (Prayitno, 2019) menyatakan bahwa dengan dilakukan supervisi akademik secara rutin terhadap guru dalam melaksanakan pembelajaran di sekolah sangat efektif dalam meningkatkan kemampuan mengajar guru SMAN 2 Bengkayang pada semester 2 tahun pelajaran 2018/2019. Kemudian penelitian yang dilakukan oleh (Merukh \& Sulasmono, 2016) menyatakan bahwa Model supervisi akademik teknik mentoring memberikan kesempatan kepada supervisor dan supervisee untuk bekerja sama dan aktif dalam pelaksanaan supervisi.

Dengan alasan itulah penulis mengangkat masalah ini sehingga program supervisi internal, berupa supervisi kelas atau kunjungan kelas oleh kepala sekolah dan guru-guru yang ditunjuk mewakili kepala sekolah membuahkan hasil sesuai yang diharapkan. Dalam rangka mewujudkan pendidikan nasional maka untuk mewujudkannya guru sebagai tenaga pendidik harus profesional. Hal ini berkaitan dengan tugas guru untuk menyiapkan generasi penerus demi masa depan yang baik. Dengan demikian, peran guru sebagai pendidik, pengajar, pelayan, pembimbing atau fasilitator, motivator dapat selalu ditingkatkan. Kualitas pembelajaran yang meningkat diharapkan akan bermuara akhir pada terjadinya peningkatan prestasi hasil belajar siswa. Dengan kondisi tersebut maka perlu diwujudkan peningkatan profesionalisme guru.

\section{Metode}

Penelitian ini adalah penelitian tindakan sekolah yang mana penelitian ini dilakukan untuk memperbaiki kemapuan guru dalam proses pembelajaran. adalah penelitian yang dilakukan oleh Kepala Sekolah atau Pengawas Sekolah. Fokus penelitian yang dilakukan oleh Kepala Sekolah sekitar supervise klinis, menyangkut aspek akademik seperti proses pembelajaran yang diselenggarakan oleh guru-guru. Pelaksanaan PTS mirip dengan PTK, yaitu bermula dari permasalahan akademik dalam ruang lingkup supervisi klinis, yang membutuhkan segera pemecahan. (Husen Windayana, n.d.; Pohan, 2017). Penelitian Tindakan Sekolah dialakukan di SMP Negeri 6 Batam yang beralamat di Jalan Laksamana Bintan Kelurahan Sei Panas, Kecamatan Batam Kota, Kota Batam Provinsi Kepulauan Riau dengan subjek penelitian guru-guru SMP Negeri 6 Batam. Jumlah guru yang diobservasi sebanyak 27 guru. Guru yang diobservasi meliputi 10 guru mata pelajaran yaitu: Guru Agama, Bahasa Indonesia, Pkn, Bahasa Inggris, Matematika, IPA, IPS, Seni Budaya, Pendididkan Jasmani dan Kesehatan, Prakarya. Penelitian ini merupakan Penelitian Tindakan Sekolah yang terdiri atas dua siklus. Metode yang digunakan untuk mengumpulkan data penelitian ini adalah studi dokumen dan observasi kelas. Metode yang digunakan untuk menganalisis data hasil penelitian ini adalah metode deskriptif. Untuk data kuantitatif dianalisis dengan mean, tabel dan grafik. Instrumen Penelitian yang dipakai dalam Penelitian Tindakan Sekolah ini terdapat 2 instrumen yaitu Observasi Pembelajaran dan Telaah Rencana Pelaksanaan Pembelajaran. Kompetensi Guru diharapkan mencapai rata-rata 81-90 dengan kategori baik pada siklus I dan pada siklus II diharapkan mencapai nilai rata-rata di atas 90 , dengan kategori amat baik.

\section{Hasil dan Pembahasan}

\section{Prasiklus}

Kondisi awal pembelajaran yang dilakukan oleh guru sebelum melaksanakan supervisi kelas akan peneliti jelaskan dalam penelitian ini. Terkait dengan penilaian terhadap kemampuan guru yang ada di SMP Negeri 6 Batam. Adapun hasil penelitian kondisi awal kemampuan guru yang ada di SMP Negeri 6 Batam secara rinci dapat dilihat pada tabel 2 di bawah ini.

Tabel 1. Penilian Kemampuan Guru dalam Pembelajaran

\begin{tabular}{cccc}
\hline No. & Kategori Penilaian & Jumlah Guru & Persentase \\
\hline 1 & Baik & 8 Orang & $29,63 \%$ \\
2 & Cukup & 19 Orang & $70,37 \%$ \\
\hline
\end{tabular}

Berdasarkan penilaian kemampuan guru pada kondisi awal (pra siklus) dapat diketahui bahwa guru yang mempunyai penilaian kemampuan pembelajaran yang baik ada 8 orang atau mencapai $29,63 \%$ dari total guru yang diamati. Sedangkan guru yang mendapat penilaian kemampuan pembelajaran yang cukup terdapat 19 guru atau $70,37 \%$ dan total guru yang diamati dalam penilaian ini. Selain ini dapat diketahui bahwa rata-rata penilaian kemampuan pembelajaran guru pada kondisi awal (pra siklus) masih ada 19 orang guru atau 74,37 \% masuk dalam kategori cukup. Dengan demikian dapat diketahui bahwa kemampuan pembelajaran guru yang ada di SMP Negeri 6 Batam pada tahun pelajaran 2017/2018 sebelum dilakukan supervisi oleh kepala sekolah masih sangat rendah. Ini berdasarkan pemantauan 
prasiklus. Berdasarkan hasil penilaian terhadap kondisi awal terkait dengan penilaian kemampuan pembelajaran guru yang masih rendah, maka perlu diakukan tindakan untuk dapat meningkatkan kemampuan pembelajaran guru yaitu dengan supervisi kelas. Salah satu upaya yang diterapkan yang akan dilakukan di SMP Negeri 6 Batam Tahun Pelajaran 2017/2018 yaitu dengan melaksanakan supervisi kelas atau akademik.

\section{Siklus 1}

Siklus 1 dilaksanakan sebanyak dua kali yaitu pertemuan 1 dan pertemuan 2 sebagai bentuk upaya untuk dapat mengatasi masalah rendahnya kemampuan pembelajaran guru yang ada di sekolah kota batam tahun pelajaran 2017/2018, maka akan dilakukan supervisi kelas atau akademik oleh kepala sekolah. Dalam pelaksanaan supervisi kepala sekoah pada siklus 1 dilakukan dengan menggunakan tenik supervisi perorangan seperti ; 1) pra observasi dengan wawancara 2) observasi, pengamatan dengan cara kunjungan kelas 3) pasca observasi, wawancara 4) tindak lanjut. Pada Pertemuan 1 supervisi dilakukan oleh peneliti secara terjadwal dengan kunjungan kelas. Pelaksanaan supervisi ini dilakukan pada awalnya seakan-akan guru merasa keberatan karena guru merasa kurang bebas melakukan pembelajaran, mereka merasa diawasi oleh kepala sekolah. Itu alasan guru yang sering disampaikan kepada kepala sekolah sebagai peneliti. Padahal hal itu bukan harus menjadi alasan. Dengan dilaksanakan supervisi guru akan mengetahui kelemahan-kelemahan dirinya pada bagian-bagian mana dalam pembelajaran yang harus ditingkatkan.

Tabel 2. Penilaian kemampuan guru siklus I pertemuan I

\begin{tabular}{ccccc}
\hline No. & Kategori Penilaian & Jumlah Guru & Persentase & Rata-rata \\
\hline 1 & Baik & 19 Orang & $70,27 \%$ & 83,79 \\
2 & Cukup & 8 Orang & $29,63 \%$ & 77,82 \\
\hline
\end{tabular}

Berdasarkan penilaian kemampuan pembelajaran guru pada siklus 1 pertemuan I dapat diketahui bahwa yang mempunyai penilaian kemampuan pembelajaran yang baik ada 19 orang guru atau mencapai $70,27 \%$ dari total guru yang diamati. Sedangkan guru yang mempunyai penilaian kemampuan pembelajaran cukup baik terdapat 8 guru atau 29,63 \% dari total guru yang diamati dalam penelitian ini. Selain itu dapat diketahui bahwa rata-rata penilaian kemampuan pembelajaran guru pada siklus 1 menunjukkan ada 70,27\% yang mencapai penilaian kemampuan pembelajaran baik. Pada pertemuan 2 pelaksanaan supervisi pada pertemuan 2 ini masih hampir sama dengan pertemuan 1, Namun guru sudah mulai terbiasa melaksanakan pembelajaran dengan pelibatan peserta didik dibanding sebelumnya yang dominan guru menguasai kelas. Segala hal yang berbentuk masukan pada pertemuan 1 menjadi perbaikan pada pertemuan 2 sehingga ada beberapa bagian dapat diperbaiki walaupun belum maksimal hasilnya. Pada pertemuan 2 ini dapat juga dilakukan dengan melakukan diskusi dan memberikan arahan kepada guru terkait dengan permasalahan yang dijumpai pada supervisi. Pada saat kepala sekolah memberikan masukan kepada guru untuk mengatasinya. Dari hasil pelaksanaan supervisi, diharapkan kepala sekolah akan dapat melakukan penilaian atau evaluasi terhadap kemampuan guru yang sesungguhnya. Dalam setiap pelaksanaan supervisi kepada sekolah memberikan penilaian terhadap aspek kemampuan pembelajaran sesuai dengan yang telah direncanakan untuk mengetahui penilaian kemampuan setiap guru dalam proses pembelajaran. Setelah kepala sekolah melakukan supervisi kelas atau akademik pada siklus 1 terdapat peningkatan kemampuan guru yang ada di SMP Negeri 6 Batam. Adapun peningkatan kemampuan guru dengan supervisi kepala sekolah dalam siklus 1 pada pertemuan kedua secara rinci dapat dilihat pada tabel di bawah ini.

Tabel 3. Penilaian Kemampuan Guru pada Siklus 1 pertemuan II

\begin{tabular}{ccccc}
\hline No. & Kategori Penilaian & Jumlah Guru & Persentase & Rata-Rata \\
\hline 1 & Baik & 22 & $81,48 \%$ & 84,19 \\
2 & Cukup & 5 & $18,52 \%$ & 79,45 \\
& Jumlah & $\mathbf{2 7}$ & $\mathbf{1 0 0} \%$ & \\
\hline
\end{tabular}

Berdasarkan penilaian kemampuan guru dalam pembelajaran pada siklus 1 dapat diketahui bahwa yang mempunyai penilaian kemampuan belum ada guru yang mencapai nilai sangat baik dari total guru yang diamati. Sedangkan guru yang mempunyai penilaian kemampuan pembelajaran baik terdapat 22 guru atau 81,48 \% dari total guru yanga ada. Begitu juga dengan penilaian guru dengan penilaian 
kemampuan cukup terdapat 5 guru atau 18,52 \% dari total guru yang diamati dalam penelitian ini. Selain itu dapat diketahui bahwa rata-rata penilaian kemampuan guru pada siklus 1 ini pertemuan II menunjukkan nilai $81,48 \%$ guru yang masuk dalam kategori baik. Dengan demikian dapat diketahui bahwa kemampuan pembelajaran guru yang ada di SMP Negeri 6 Batam mengalami peningkatan setelah dilaksanakan supervisi oleh kepala sekolah dari yang semula mempunyai rata-rata 70,37 \% pada pertemuan I meningkat menjadi 84,19 \% pada pertemuan II. Berdasarkan hasil evaluasi dari pelaksanaan siklus 1 pada penelitian ini dapat diketahui bahwa terdapat peningkatan kemampuan guru yang ada di SMP Negeri 6 Batam. Meski demikian peningkatan kemampuan pembelajaran guru pada siklus ini belum mampu mencapai target yang telah ditetapkan yaitu lebih dari $85 \%$ guru mempunyai penilaian kemampuan pembelajaran yang baik. Dari hasil pelaksanaan supervisi kepala sekolah pada siklus 1 masih terdapat banyak kekurangan yang masih perlu diperbaiki agar mampu menghasilkan aktivitas pembelajaran yang efektif. Dalam pelaksanaan supervisi pada siklus 1 belum dilaksanakan secara matang mengingat perencanaan yang dilakukan masih terbatas pada perencanaan yang sederhana. Perencanaan kegiatan supervisi yang dilaksanakan pada siklus 1 belum dilakukan secara terstruktur dengan baik. Selain itu kurangnya koordinasi antara kepala sekolah dengan guru dalam pelaksanaan supervisi. Kepala sekolah kadang-kadang kurang dapat memanfaatkan fasilitas dan sumber daya yang ada di sekolah guna mendukung kegiatan supervisi. Sebagai bentuk refleksi dalam penelitian ini, masih dibutuhkan perencanaan yang lebih matang untuk menghasilkan supervisi pembelajaran yang lebih efektif. Selain itu diperlukan adannya koordinasi antara kepala sekolah dengan guru guna meningkatkan efektiviitas pelaksanaan supervisi ini. Untuk itu dalam pelaksanaan supervisi ini perlu dilakukan perbaikan pada siklus berikutnya.

\section{Siklus II}

Dalam siklus II dilaksanakan 2 kali pertemuan yaitu pertemuan 1 dan pertemuan 2. Sebagai bentuk refleksi dari pelaksanaan supervisi pembelajaran yang telah dilakukan pada siklus I dalam rangka meningkatkan kemampuan guru di SMP Negeri 6 Batam Tahun Pelajaran 2018/2019. Dalam pelaksanaan supervisi pembelajaran pada siklus II pada dasarnya sama dengan apa yang telah dilaksanakan yaitu ada 2 siklus yaitu siklus I dengan menggunakan teknik supervisi perorangan seperti ; 1) kunjungan kelas, 2) percakapan pribadi, 3) kunjungan antar kelas, 4) penilaian sendiri. Meskipun demikian supervisi pada siklus II ini dilakukan perencanaan yang lebih matang dengan melibatkan guru dan melakukan koordinasi antara kepala sekolah dengan guru dalam rangka upaya meningkatkan motivasi dan kinerja guru. Kepala sekolah lebih serius dalam melakukan kunjunga ke masing-masing kelas, melakukan diskusi dengan guru mapel menanyakan tentng keadaan dan perkembangan kelas yang diasuh oleh masing-masing guru, kepala sekolah juga melibatkan guru-guru lain dalam aktivitas di luar kelas, dan kepala sekolah juga memberikan kesempatan kepada guru untuk berupaya mengembangkan kreativitasnya dalam mengajar. Kepala sekolah juga memberikan arahan kepada setiap guru untuk memanfaatkan segala fasilitas dan sumber daya yang ada di sekolah guna mendukung proses pembelajaan yang lebih baik. Dalam melaksanakan supervisi pada siklus II ini, kepala sekolah juga menanyakan kepada anak didik tentang kondisi belajar yang ada di kelas masing-masing, selain itu kepala seklolah juga selalu berupaya untuk memberikan dukungan baik fisik maupun mental terhadap semua guru maupun peserta didik dalam meningkatkan prestasi belajar perserta didik. Kepala sekolah selalu memberikan kesempatan kepada para guru untuk menyampaikan aspirasi atau pendangan dalam upaya meningkatkan proses belajar di sekolah. Dengan adanya kegiatan supervisi pada siklus II ini, maka diketahui hasil penilaian terhadap kemampuan pembelajaran guru di SMP Negeri6 Batam tahun pelajaran 2017/2018 terjadi peningkatan. Adapun peningkatan kemampuan guru dengan adanya pelaksanaan supervisi oleh kepala sekolah dalam siklus II secara rinci dapat dilihat pada tabel di bawah ini.

Tabel 4. Penilaian Kemampuan Guru pada Siklus II pertemuan I

\begin{tabular}{ccccc}
\hline \multirow{2}{*}{ No. } & \multirow{2}{*}{ Kategori Penilaian } & Jumlah & Persentase & Rata-Rata \\
\hline 1 & Baik & 22 Orang & $81,48 \%$ & 86,85 \\
2 & cukup & 5 Orang & $18,52 \%$ & 80,60 \\
& Jumlah & 27 & $100 \%$ & \\
\hline
\end{tabular}

Berdasarkan penilaian kemampuan guru pada siklus II dapat diketahui bahwa guru yang mempunyai penilaian kemampuan pembelajaran yang baik ada 22 guru atau mencapai 81,40\% dari total guru yang diamati. Sedangkan guru yang mempunyai penilaian kemampuan pembelajaran yang cukup 
terdapat 5 guru atau 18,52\% dari total guru yang diamati dalam penelitian ini. Pada pertemuan 2 kegiatan supervisi pada siklus II di pertemuan II diperoleh data sebagai berikut,

Tabel 5. Penilaian kemampuan guru siklus II pertemuan II

\begin{tabular}{ccccc}
\hline No. & Kategori Penilaian & Jumlah Guru & Persentase & Rata-Rata \\
\hline 1 & Baik Sekali & 3 Orang & $11,11 \%$ & 91,17 \\
2 & Baik & 20 Orang & $74,07 \%$ & 83,14 \\
3 & cukup & 4 Orang & $14,81 \%$ & 80,73 \\
& Jumlah & 27 & $100 \%$ & \\
\hline
\end{tabular}

Dari data di atas dapat dilihat terjadi peningkatan penilaian kemampuan guru. Yang semula pada pertemuan I belum terlihat ada penilaian dengan kategori sangat baik, pada pertemuan kedua ini terdapat 3 orang 11,11\% dari 27 orang guru yang diamati yang mendapat predikat sangat baik. Sedangkan ada 20 orang atau 74,04\% yang mendapat predikat baik, dan masih ada 4 orang guru atau 14,81\% yang masih mendapat penilaian cukup. Namun angka ini sudah banyak menunjukkan peningkatan dibandingkan dengan kondisi awal sebelum diadakan supervisi yang berkelanjutan. Berdasakan hasil evaluasi dari pelaksanaan siklus II pada penelitian ini dapat diketahui bahwa terdapat peningkatan kemampuan pembelajaran guru yang di SMP Negeri 6 Batam. Kemampuan pembelajaran dalam siklus II menunjukkan peningkatan yang cukup signifikan yaitu dari hasil penilaian kemampuan guru pada siklus II ini menunjukkan bahwa penilaian kemampuan pembelajaran guru menunjukkan penilaian yang baik. Dengan demikian dapat dipastikan bahwa pelaksanaan supervisi oleh kepala sekolah yang dilaksanakan secara berencana dan terstruktur akan dapat menghasilkan proses supervisi yang lebih baik. Hal ini terbukti bahwa dengan perencanaan yang lebih matang dan pelaksanaan yang lebih terintegrasi antara guru dan pihak-pihak lain yang terkait dengan segala aktivitas yang ada di sekolah baik di dalam kelas maupun di luar kelas akan dapat menghasilkan proses supervisi yang baik. Dengan proses supervisi yang baik mampu meningkatkan kemampuan guru. Dengan pelaksanaan supervisi yang dilaksanakan kepala sekolah pada siklus II ini terbukti mampu meningkatkan kemampuan pembelajaran guru yang baik. Pelaksanaan supervisi tersebut telah tercapai target pencapaian tindakan yaitu 81,48 \% guru telah menunjukkan kemampuan yang baik dan 11,11 \% guru sudah menunjukkan kemampuan yang sangat baik. Artimya sudah lebih dari 85 \% guru menunjukkan kemampuan pembelajaran yang baik.

Pembahasan

Berdasarkan hasil penelitian tindakan sekolah yang terkait dengan upaya meningkatkan kemampuan pembelajaran guru melalui pelaksanaan supervisi oleh kepala sekolah yang di laksanakan di SMP Negeri 6 Batam tahun pelajaran 2017/2018 maka dapat dijelaskan dalam pembahasan berikut ini. Pelaksanaan supervisi oleh kepala sekolah di SMP Negeri 6 Batam selama ini belum dapat dilaksanakan secara efektif. Namaun setelah pelaksanaan tindakan ini membuktikan bahwa pelaksanaan supervisi oleh kepala sekolah mampu memberikan kontribusi yang positif terhadap peningkatan kemampuan pembelajaran guru di SMP Negeri 6 Batam tahun Pelajaran 2017/2018. Hal ini terbukti dari adanya peningkatan penilaian kemampuan pembelajaran guru pada saat pra siklus, siklus I, dan siklus II.

Berdasarkan hasil penelitian ini dapat diketahui bahwa pelaksanaan supervisi oleh kepala sekolah yang dilaksanakan secara berkesinambungan terbukti dapat meningkatkan kemampuan pembelajaran guru. Untuk itu pelaksanaan supervisi oleh kepala sekolah secara berkesinambungan dapat selalu dilaksanakan dalam rangka mempertahankan sekaligus meningkatkan kemampuan pembelajaran guru. Dalam pelaksanaan supervisi oleh kepala sekolah perlu dilakukan perencanaan yang terstruktur dan dilaksanakan secara sistematis agar mampu menghasilkan proses supervisi yang baik. Dengan adanya pelaksanaan supervisi yang baik diharapkan akan dapat meningkatkan kemampuan pembelajaran guru guna mendukung pencapaian tujuan pembelajaran yang lebih baik (Hadi, 2019; Nugraha, 2015). Karena telah mencapai target yang diinginkan dalam peningkatan kemampuan pembelajaran guru di siklus II, maka penelitian ini tidak dilanjutkan lagi.

Hasil penelitian ini sejalan dengan hasil penelitian yang dilalakukan oleh Aini pada tahun 2017 dengan judul Upaya Meningkatkan Kompetensi Guru Dalam Proses Pembelajaran Berdasarkan Kurikulum 2013 Melalui Supervisi Akademik Semester Satu Tahun Pelajaran 2017/2018 Di SD Negeri 5 Mataram. Hasil penelitian pada siklus I observasi Kepala Sekolah rata-rata $(2,80)$, observasi guru rata-rata $(3,00)$ dan hasil supervisi akademik guru kelas rata-rata nilai $(61,35)$. Pada siklus II observasi kepala Sekolah rata-rata $(3,50)$, observasi guru rata-rata $(4,00)$ dan hasil supervisi akademik di sasaran rata-rata nilai $(78,73)$. Siklus III observasi kepala Sekolah rata-rata $(4,50)$, observasi guru rata-rata $(4,50)$ dan hasil supervisi akademik di sasaran rata-rata nilai $(86,25)$. Indikator keberhasilan telah tercapai, penelitian dinyatakan berhasil dan dihentikan pada siklus III. Selanjutnya penelitian yang dilakukan oleh Mujiyana 
pada tahun 2019 dengan judul Upaya Meningkatkan Kompetensi Guru melalui Supervisi Akademik Teknik Individual Kunjungan Kelas di MIN 1Gunungkidul TahunAjaran 2018/2019. Hasil penelitian menunjukkan adanya peningkatan kompetensi guru dari hasil supervisi akademik terhadap 13 guru yang menjadi objek penelitian mengalami peningkatan kemampuan dalam merencanakan dan melaksanakan pembelajaran. Peningkatan kompetensi ditandai dengan kemampuan berikut: 1) membuat RPP yang sesuai dengan kaidah kurikulum 13,2) melaksanakan proses pembelajaran sesuai dengan silabus dan RPP, dan 3) melaksanakan penilaian sesuai dengan standar penilaian.

\section{Simpulan Dan Saran}

Penelitian Berdasarkan penelitian yang telah dilakukan dapat disimpulkan bahwa pelaksanaan supervisi oleh kepala sekolah yang dilaksanakan secara berkesinambungan terbukti dapat meningkatkan kemampuan pembelajaran guru.

Saran yang dapat diajukan berdasarkan penelitian yang telah dilakukan adalah sebagai berikut Guru diharapkan bisa menjadi motivator dan fasilitator dalam proses pembelajaran, guru harus bisa memaksimalkan kemampuan memanfaatkan media pembelajaran dalam proses pembelajaran sehingga siswa lebih aktif dan antusias dalam proses pembelajaran. Dengan demikian akan tercipta suasana pembelajaran yang menyenangkan di dalam kelas dan tercipta kolaborasi yang baik antara siswa dengan guru.

Supervisi kelas atau akademik hendaknya dilakukan secara berkelanjutan agar dapat memotivasi guru dalam peningkatan profesionalismenya.

\section{Daftar Rujukan}

Adha, Maulana Amirul. (2019). Analisis Komparasi Sistem Pendidikan Indonesia dan Finlandia. Jurnal Studi Manajemen Pendidikan vol. 3, no. 2, November 2019. http://dx.doi.org/10.29240/jsmp.v3i2.1102

Aini, Baiq. (2017). Upaya Meningkatkan Kompetensi Guru Dalam Proses Pembelajaran Berdasarkan Kurikulum 2013 Melalui Supervisi Akademik Semester Satu Tahun Pelajaran 2017/2018 Di SD Negeri 5 Mataram. Jurnal Pendidikan Mandala Volume 2 Nomor 2. http://dx.doi.org/10.36312/jupe.v2i2.203

Djihadah, Nuryati. (2020). Kecerdasan Emosional dan Kepemimpinan Kepala Madrasah dalam Aplikasi Penguatan Pendidikan Karakter (PPK) di Madrasah. Jurnal Pendidikan Madrasah, Volume 5, Nomor 1, Mei 2020. https://doi.org/10.14421/jpm.2020.51-01

Firmansyah, Dani. (2015). Pengaruh Strategi Pembelajaran Dan Minat Belajar Terhadap Hasil Belajar Matematika . Jurnal Pendidikan Unsika Volume 3 Nomor 1, Maret 2015. https://journal.unsika.ac.id/index.php/judika/article/view/199

Hadi, S. (2019). Supervisi Akademik Kunjungan Kelas Oleh Kepala Sekolah Dalam Rangka Meningkatkan Kinerja Guru ( Studi Kasus Di SMP NW Jerua ). Fondatia : Jurnal Pendidikan Dasar, 3(2), 114-135. https://doi.org/https://doi.org/10.36088/fondatia.v3i2.371

Husen Windayana. (n.d.). Penelitian Tindakan Sekolah. Eduhumaniora, 4(1), 79-91. https://doi.org/10.11151/eds1951.5.79

Merukh, N., \& Sulasmono, B. S. (2016). Pengembangan Model Supervisi Akademik Teknik Mentoring Bagi Pembinaan Kompetensi Pedagogik Guru Kelas. Kelola: Jurnal Manajemen Pendidikan, 3(1), 30. https://doi.org/10.24246/j.jk.2016.v3.i1.p30-48

Mujiyana. (2019). Upaya Meningkatkan Kompetensi Guru melalui Supervisi Akademik Teknik Individual Kunjungan Kelas di MIN 1Gunungkidul TahunAjaran 2018/2019. Jurnal Pendidikan Madrasah, Volume 4, Nomor 1.

Muspawi, M. (2017). Implementasi Supervisi Akademik pada MAN Insan Cendekia Provinsi Jambi. Ta'dib: Jurnal Pendidikan Islam, 6(2), 49-56. https://doi.org/10.29313/tjpi.v6i2.3181

Nugraha, M. S. (2015). Pelaksanaan Supervisi Akademik oleh Kepala Madrasah Aliyah Swasta di Kabupaten Sukabumi Jawa Barat. Nadwa, 9(1). https://doi.org/10.21580/nw.2015.9.1.520

Nurkholis. (2013). Pendidikan Dalam Upaya Memajukan Teknologi . Jurnal Kependidikan, Vol. 1 No. 1 Nopember 2013. DOI: https://doi.org/10.24090/jk.v1i1.530 
Pohan, N. (2017). Peran Supervisi Kepala Sekolah Terhadap Pelaksanaan Tugas Pokok Guru: Penelitian Tindakan Sekolah. JPD: Jurnal Pendidikan Dasar, 1(3), 132-139. http://journal.unj.ac.id/unj/index.php/jpd/article/view/9527

Prayitno, P. J. (2019). Pelaksanaan Supervisi Akademik Untuk Meningkatkan Kompetensi Pedagogik Guru SMA. Jurnal Visi Ilmu Pendidikan, 11(2), 46. https://doi.org/10.26418/jvip.v11i2.33209

Sholichah, Aas Siti. (2018). Teori-Teori Pendidikan Dalam Al-Qur'an. Jurnal Edukasi Islami Jurnal Pendidikan Islam Vol. 07/No.1, April 2018. http://dx.doi.org/10.30868/ei.v7i01.209

Suryana, Yudho Ramafrizal. (2018). Kajian Model Pembelajaran Kooperatif Tipe STAD (Student Teams Achievement Division) Dalam Upaya Meningkatkan Efektifitas Proses Belajar Mengajar Akuntansi. Jurnal Kajian Pendidikan Ekonomi dan Ilmu Ekonomi, ISSN Online: 2549-2284 Volume II Nomor 2, Juli 2018. http://dx.doi.org/10.23969/oikos.v2i2.1049

Sutrisno. (2016). Berbagai Pendekatan Dalam Pendidikan Nilai Dan Pendidikan Kewarganegaraan . Jurnal Dimensi Pendidikan dan Pembelajaran Vol.5 Januari 2016. DOI : 10.24269/dpp.v4i1.56

Widodo, Heri. (2016). Potret Pendidikan Di Indonesia Dan Kesiapannya Dalam Menghadapi Masyarakat Ekonomi Asia (Mea). Jurnal Cendekia Vol. 13 No. 2, Juli - Desember 2015. https://doi.org/10.21154/cendekia.v13i2.250 